Diploma courses will not be overlooked. Stress is laid on the need for flexibility in this development, of which a synopsis is included in the pamphlet, together with some notes on the particular courses.

\section{The Harkness Fellowships of the Commonwealth} Fund-New York

ThIRTy Harkness fellowships of the Commonwealth Fund-Now York are tenable during 1962 for education and travel in the continental United States. The fellowships are offered to candidates from the United Kingdom, Australia, New Zealand and Western Europe, who are British subjects and either are graduates or have experience in Government service, the professions, the arts, branches of business or industry or other comparable careers or vocations, and have the equivalent of a degree in qualifications conferred by professional bodies or an attested level of professional competence. Forms of application, which must be returned before November 15 , can be obtained from the Warden, Harkness House, 38 Upper Brook Street, London, W.1, from whom further details can be obtained.

\section{The Institute of Scientific Information}

A BROCHURE describing the services, publications and techniques adopted by the Institute for Scientific Information (Philadelphia, Penn.) has now been issued by the Institute, to which Eugene Garfield, its director, contributes a foreword. He states that the primary purpose of the Institute is to increase the productivity of research through a programme of dissemination and retrieval of information, screening, coding and indexing systems, design, research and development. The brochure describes the scope of Current Contents and the Index Chemicus, the Index Medicus programme, the Citation Index project and the three projects still in development: the transliterating typewriter, the National Newspaper of Science, and the National Directory of Science.

\section{Polish Textile Research}

The journal of the Politechnika Lodźka (Zeszyty Naukowe Politechniki Lodzkiej) is published in five sections, corresponding to chemistry, applied chemistry, electricity, mechanics, and textiles. Volumes 6 and 7 of the textile section have been issued, and provide some ten extensive papers on subjects ranging from the variable delivery of metering pumps to the cleaning of bast fibres by passing them through fluted rollers. The work is described in great detail (in Polish) with summaries in Polish, English and Russian. The reports are of high standard, and should be available in textile laboratories. Copies can be obtained from the Politechnika Lodźka, ul. Gdańska 155, Łodź.

\section{Announcements}

Dr. Fabian Recalde, former director of the National Institute of Nutrition in Quito, Ecuador, has been appointed to the staff of the Food and Agriculture Organization as a nutrition officer. Dr. Recalde's task will be the co-ordination of field projects in Latin America that require joint action by the Organization and the United Nations Chil dren's Fund. These projects chiefly concern improving material and child nutrition.

DR. E. L. Powers, associate director, Division of Biological and Medical Research, Argonne National
Laboratory, Illinois, will deliver the seventh Douglas Lea Memorial Lecture, entitled "New Considerations on Survival Curves and Target Theory", at a meeting of the Hospital Physicists' Association, at 5.15 p.m. on September 15, in the Chemistry Department, University of Leeds. Further information can be obtained from Dr. J. R. Mallard, Department of Physics, Hammersmith Hospital, Ducane Road, London, W.12.

THE fifth international conference on "Pigment Cell Biology" is being sponsored by the New York Academy of Sciences and will be held in New York City during October 11-14. The conference will deal with melanoma and closely related fields. Further information can be obtained from Vernon. Riley, Sloan-Kettering Institute for Cancer Research, New York 21, N.Y.

THE fourteenth international instructional course on "Fine Measuring Instruments" is being held by Carl Zeiss, Jena, at the Imperial College of Science and Technology, London, during September 11-22. Further information can be obtained from Carl Zeiss Scientific Instruments, Ltd., $12 a$ Golden Square, London, W.1.

The newly formed American Society for Cell Biology is holding a meeting at the Edgewater Beach Hotel, Chicago, Illinois, during November 2-4. Three symposia are included in the programme, which will cover: cell continuity; cell diversification; characteristics of cell interfaces. Further information can be obtained from Montross J. Moses, Acting Secretary, American Society for Cell Biology, Box 2982, Duke University School of Medicine, Durham, North Carolina.

The Food and Agriculture Organization is sponsoring an international conference on "Fish in Nutrition" in Washington, D.C., during September 19-27. The programme will include: the role of fish in world nutrition; chemical composition of fish and fishery products; contribution of fish and fish products to national diets; fish and fishery products in animal nutrition; demand for fish as human food and possibilities for increased consumption. Further information can be obtained from the headquarters of the Food and Agriculture Organization, Viale delle Terme di Caracalla, Rome.

A COURSE for young naturalists with a strong interest in conservation is run annually by the Verein Naturpark in the Lüneburger Heide, North Germany. The participants are given first-hand knowledge of the theoretical and practical sides of conservation. Information can be obtained from the camp secretary of the International Youth Federation for the Study and Conservation of Nature, Reiner Lidauer, Paracelsusstrasse, 6, Salzburg, Austria, or from Derek S. Davis, 56 Altmore Avenue, East Ham, London, E.6, of the British Co-ordinating Group of the International Youth Federation.

Erratum. In the article entitled "Effect of Poly. vinyl Alcohol on the Distribution of Iodine-131 in the Internal Organs, Fluids and Excreta of Rabbits", by H. F. Nowak and J. Kucharski, in Nature of August 12 , p. 665 , the sentence beginning at line 14 from the end should read: "Administration of iodine131 with polyvinyl alcohol caused it to collect in smaller quantities in the parenchymal organs and thus the possibility of injury to these organs is considerably reduced". 